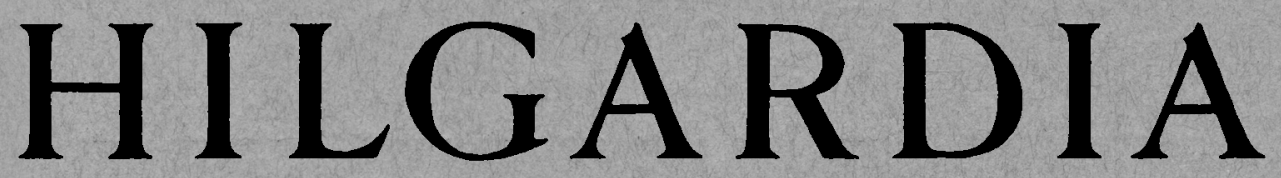

A Journal of Agricultural Science Published by

the California Agricultural Experiment Station

\title{
OBSERVATIONS ON THE SYMBIOTES OF CERTAIN COCCIDAE
}

\author{
EDWARD A. STEINHAUS
}




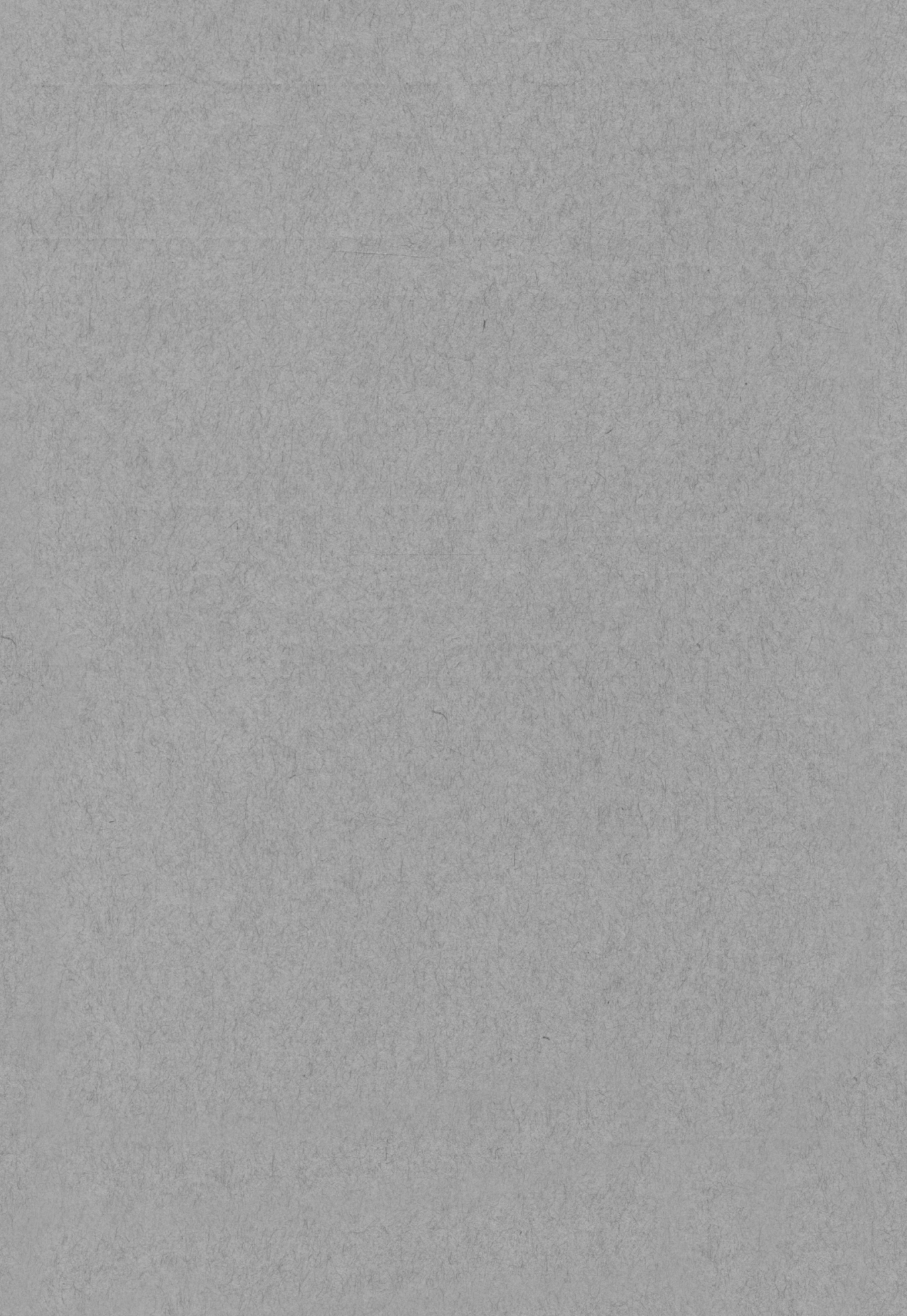




\section{H I L \\ A Journal of Agricultural Science Published by \\ the California Agricultural Experiment Station \\ VoL. 24 \\ DECEMBER, 1955 \\ No. 8}

\section{OBSERVATIONS ON THE SYMBIOTES OF CERTAIN COCCIDAE ${ }^{1}$}

\section{EDWARD A. STEINHAUS ${ }^{2}$}

\section{INTRODUCTION}

IN THE COURSE of his studies on the anatomy of Coccus hesperidum Linn., Leydig $(1854)^{3}$ observed small lanceolate-shaped bodies in the hemolymph of this insect. More than thirty years later their organismal nature was definitely recognized (Moniez, 1887 ; Lindner, 1895; Šlule, 1906), and they became known as yeastlike symbiotes probably playing a beneficial role in the life of their host. They have been found to be present in all species of Coccidae examined, and in every individual of the species, being transmitted from one generation to the next through the egg. Of interest is the fact that the Diaspididae, or armored scales, do not harbor these yeastlike microorganisms in their hemolymph, although other types of symbiotes may be found in other locations in these insects.

Although certain coccids have been reported to be susceptible to certain microbial pathogens, especially certain fungi, the use of microorganisms as control agents against these insects has, so far, not proved to be generally practical. In view of this state of affairs, the writer has for some time toyed with the idea that possibly the relationship between the symbiote and the host insect could be altered so as to be detrimental to the insect and perhaps to cause its death. Theoretically this might be accomplished in one of two ways: (1) Circumstances might be created that would destroy the symbiote even though they would not directly affect the insect. If, as is known to be true with some insects, the life of the host insect is dependent upon the symbiote, destruction of the latter would mean the death of the insect. This is known to occur in certain other insect species. (2) The environment of the insect might be altered in a manner that would cause the symbiote to become pathogenic for its host (a possibility suggested by R. H. Smith, 1944) or to multiply to a degree that would cause the death of its host. It is conceivable

${ }^{1}$ Contribution from the Laboratory of Insect Pathology, Department of Biological Control, University of California, Berkeley. Part of a report on an investigation generously supported by a grant from the U. S. Public Health Service, Grant No. G4069(C). Submitted for publication April 20, 1955.

${ }^{2}$ Professor of Insect Pathology and Insect Pathologist in the Experiment Station.

${ }^{3}$ See "Literature Cited" for citations, referred to in the text by author and date. 
that if the yeastlike symbiotes were to increase greatly in size or number the moisture content of the insect would greatly decrease, the nutritional balance of the insect tissues would be altered, and waste products or metabolites from the rapidly developing symbiote would accumulate. Such changes would certainly be to the detriment of the host insect.

It was with such ideas in mind that we undertook what we considered to be the first steps toward the possible realization of controlling certain scale insects by altering the biological relationships between them and their symbiotes. Unfortunately, the results obtained in this investigation have not been very encouraging. They appear to be worth reporting, however, for whatever value they may have to other workers interested in the same objectives. They are being reported at this time because of the necessity of our abandoning this particular project; there is still room for a thorough investigation.

Most of the experimentation here described was accomplished with the brown apricot scale, Lecanium corni Bouché, living on pear trees (Pyrus). Some observations, however, were made on the symbiotes of the kuno scale, Lecanium kunoensis Kuwana; the black scale, Saissetia oleae (Bern.) ; and the nigra scale, Saissetia nigra (Niet.). They were brought to the laboratory on twigs of various host plants growing in the Bay Area, especially just east of Berkeley, California.

\section{DESCRIPTION OF SYMBIOTES}

The symbiotes of Lecanium corni, Saissetia oleae, and Saissetia nigra have already been described by previous authors. To our knowledge, however, this is the first report of yeastlike symbiotes in Lecanium kunoensis. In all of these species the symbiotes are found regularly in the hemolymph and fat tissue of every individual (figures 1 to 4 ). They are transmitted from one generation to the next through the egg. (See Granovsky, 1929; Buchner, 1953). The exact role of the symbiotes in their relationship to the host insects is not known but it is assumed to be one of mutualistic symbiosis. The total number of symbiotes contained in an individual insect varies according to the stage and age of the insect, old adult females usually harboring fewer than the developing immature stages. With the latter, it has been estimated that 300 to 500 symbiotes occur in each insect. Ordinarily, in the immature insects, the symbiotes are situated toward the periphery of the body cavity (fig. 1), whereas in the adult females they are more or less evenly distributed throughout that part of the body cavity occupied by fat tissue.

The symbiote of $L$. corni was given the name Coccidomyces rosae by Buchner in 1911. Brain (1923), in his attempt to classify the intracellular symbiotes of insects, placed Buchner's species in his new genus Lecaniocola. Buchner (1912) described the symbiote as an elongated organism, usually with one end pointed and the other rounded but sometimes with both ends pointed. Budding occurs at the more pointed end. The protoplasm is diffusely granular. The length is about 8.5 microns. Our own observations confirm this original description (which, incidentally, applies in general to most of the yeastlike symbiotes of coccids), except that we found the size to vary in width from 2.5 to 4.0 microns, and in length from 5.0 to 15.5 microns (fig. 5 ). 
The average dimensions were 3.2 by 9.7 microns. At certain times the symbiotes may appear as greatly elongated forms (around 100 microns in length); the possible significance of these forms will be discussed later in this paper. On occasion compact groups were seen (fig. 6) in which the rather amorphous and hyaline appearing yeastlike bodies were congregated. The significance of these forms is not known; possibly they represent a sort of developmental or reproductive stage of the symbiote.

In 1907, Conte and Faucheron reported the presence of yeastlike forms in the black scale, S. oleae. The most thorough study of the symbiote of this insect, however, was that made by Granovsky (1929) who named it Lecaniocola saissetiae. In all essential respects our observations on the morphology of the symbiote (figures 7 and 8 ), as well as the results of our attempts to cultivate the organism, corresponded to those of Granovsky.

The symbiote of S. nigra was apparently first seen by Evernham and reported by R. H. Smith (1944), but it was not described beyond saying that the organism was "identified as a species of Torulopsis or Rhodturla." Subsequently, the writer (Steinhaus, 1951) figured the symbiote and briefly described it morphologically.

The symbiote of $L$. kunoensis does not appear to have been previously described. In its principal morphological characteristics it does not appear to differ in any important respect from the symbiotes found in other coccids (figures 9 and 10). A variety of shapes is encountered; usually one end (sometimes both ends) is pointed and the other rounded. Budding occurs at the pointed end. The protoplasm is granular, and two or three small vacuoles may be present. The width of the symbiote varies from 1.6 to 5.0 microns, the length from 4.5 to 50.0 microns, with the average dimensions about 3.4 by 14.0 microns.

In spite of the fact that some of the symbiotes from coccids have been given scientific names by their describers, their exact relation to other microorganisms is not clear. Although yeastlike in appearance, in many respects they resemble the blastospores or sprout cells of certain fungi such as those of the genus Pullularia (=Dematium). There are well-known examples in vertebrate pathology in which a mycelium-forming fungus appears in the form of a yeast when in animal tissues. A similar phenomenon may be occurring with the yeastlike symbiotes in insects. In any event, such names as Coccidomyces and Lecaniocola are without any real phylogenetic significance as far as their relation to other groups of fungi or true yeasts is concerned. Clarification of the true systematic status of these symbiotes cannot be expected until they have yielded to cultivation on artificial media.

\section{CULTIVATION EXPERIMENTS}

It appears obvious that progress toward gaining an understanding of the factors that might be important in any disturbance of the relationship between the symbiote and its host insect could be aided materially if the symbiote were first isolated and grown on an artificial medium. Certainly a more accurate knowledge of its physiological characteristics could thus be obtained. Furthermore, although the symbiotes of Coccidae have usually been 
considered to be yeasts or yeastlike organisms, and in some instances given scientific names, many workers have recognized that a revelation of their true nature awaits their certain cultivation on artificial media.

Attempts (Lindner, 1895; Berlèse, 1905; Conte and Faucheron, 1907; Brues and Glaser, 1.921; Schwartz, 1924; and Benedek and Specht, 1933) to isolate and grow the symbiotes from soft-scale insects have either been unsuccessful or have lacked confirmation. Schwartz reported limited growth, in liquid media, of the yeastlike symbiote of Lecanium corni. Benedek and Specht claimed cultivation, in a glucose broth, of the same symbiote, and named it Torula lecanii corni. They maintained cultures of the organism on Sabouraud's glucose agar medium.

Our own efforts to cultivate the symbiotes from the coccids studied in this investigation met with no certain success beyond the limited growth and budding of individual symbiotes held in hanging drop preparations. Hansen's solution and malt extract broth were used as nutrients. Most of our cultivation experiments were done with the symbiotes from Lecanium corni, Lecanium kunoensis, and Saissetia nigra. A variety of methods and procedures was used. The methods, as well as the types of media, used by Schwartz, by Benedek and Specht, and some of those by Müller (1934) were tried, and the essential aspects of their experiments repeated. Liquid media, such as Hansen's solution, glucose broth, Mycophil broth, and malt extract broth ; and solidified media, such as malt extract agar, wort agar, and potato dextrose agar, were used as trial media. Media to which an infusion of crushed coccids was added were also tried, as was the aseptically drawn hemolymph of lepidopterous larvae (Junonia coenia Hbn.). Hanging drop (or moist culture chamber) methods of culturing were employed in addition to the orthodox microbiological culture techniques. Numerous attempts to grow the symbiotes were also made using microaerophilic and anaerobic media and methods.

Initially, the results of our cultivation experiments indicated that the symbiotes were being grown on malt-extract agar without much difficulty. Colonies of yeastlike organisms developed on plates inoculated with the triturated bodies of the insects as well as on plates inoculated with the body contents (removed with a sterile capillary pipette) of the insects, sometimes even after washing the insect in tincture of Merthiolate. Although usually slightly greater in size, the organisms grown in culture were morphologically very similar to the symbiotes in the insects (fig. 11). After a comprehensive morphological and physiological study of the several strains isolated, they were identified as strains of those fungi commonly known as the "black yeasts," of which the single best known species is Pullularia pullulans (De Bary) Berkhout (= Demátium pullulans De Bary). These organisms are not true yeasts but rather fungi, although, as pointed out by Mrak and Phaff (1948), it is difficult to exclude this commonly encountered genus from a discussion of yeasts. As a group they have not been well studied, and a review of the literature pertaining to them is frequently confusing and somewhat trying." Strains of $P$. pullulans were recovered from cultures made of each of the four different species of coccids studied in this investigation.

\footnotetext{
- The nomenclatorial history of the type species Pullularia pullulans begins in the year
} 
The strains of Pullularia pullulans isolated during the present investigation exhibited (except for minor variations, of which many occur in this species) essentially the same characteristics by which this species has been described in the literature. On malt agar, we found young cultures to possess a brownish cream color with a hint of rose. The surface was moist. After three days, colonies averaged about $8 \mathrm{~mm}$ in diameter, with the centers slightly raised. The periphery frequently showed some flat mycelial growth with white aerial hyphae. After eight days, the colonies had frequently increased in diameter to $20 \mathrm{~mm}$, their periphery showing a ring of aerial and lateral hyphae. The color of the colony had darkened, and the surface sometimes pocked with small indentations. Although cultures of most of the strains isolated eventually darkened to the point of blackness, they did not do this as readily as did strains we obtained from type culture collections. On malt agar no appreciable blackness occurred after five months; most strains became black after 10 to 30 days on potato dextrose agar.

Our strains assimilated glucose, sucrose, maltose, raffinose, and insulin. They did not assimilate lactose or galactose, although strains from other sources did assimilate all of these sugars or all but lactose. Under proper conditions they were capable of fermenting glucose, as determined by the Conway test for alcohol. Acid and gas were formed in glucose, sucrose, maltose, and raffinose. Ordinarily, after three days in glucose the growth of hyphae may be noted. The buds arising from the hyphae are very elongate, and arise in clusters. There may be profuse branching at right angles to the hypha. Blastospores (about 4 by 8 microns) form, sometimes arising in clusters on small protuberances on the hyphae. In sucrose, the blastospores on the hyphae are very numerous, small ( 2.5 by 4.7 microns), arising singly or in clusters on small protuberances.

Some strains were able to assimilate ethyl alcohol slightly; and some strains produced starch, although in varying amounts.

The size of the yeastlike cells or blastospores on malt agar varied somewhat with the age of the culture. After 24 hours they averaged about 4.5 by

1797 when Persoon presented in his Observations Mycologicae the generic name Dematium. In this genus (which he had described in 1794) he included four species found associated with plants and their foliage. De Bary, in 1866, gave the name Dematium pullulans to a fungus commonly found on the surface of plants and which multiplied by "sprout cells" very similar in form to some species of Saccharomyces with which they had been frequently confused. About a year later Loew (1867) added to De Bary's description and presented the results of a detailed study of the fungus which, he says, may frequently be encountered on the surface of fruit. Following this, a number of reports, some of them contradictory, appeared, and aided in gradually clarifying the nature of the fungi concerned. These reports included those by Frank (1886), Constantin (1888), Laurent (1888), Janczewski (1892), Zopf (1890), Massee (1898), Berlèse (1895), Klocker and Schionning (1900), Planchon (1900), Brooks and Hansford (1923), and Hoggan (1924).

Hoggan's presentation did not refer to an important paper by Berkhout (1923) who proposed the name Pullularia. She removed pullulans from the genus Dematium because, contrary to the definition of the genus, this species does not carry conidia vertically, nor do chains of conidia occur; instead they originate as lateral sprouts on the mycelial threads. Inasmuch as the fungus could not be assigned to any other known genus, Berkhout proposed the generic name Pullularia for which Pullularia pullulans (De Bary) became the type species. Subsequent writers (e.g., Dodge, 1935; Negroni and Fischer, 1942 ; and others) have, for the most part, followed Berkhout's revision. 
11.5 microns; after three days they averaged about 2.5 by 10 microns; after seven days they measured approximately 3.5 by 15 microns.

$P$. pullulans is ordinarily considered to be a saprophyte, although it has been recovered from certain types of lesions in vertebrates. Cursory tests were run to determine its possible pathogenicity for insects. In general it was found that while the injection of small amounts of relatively thin suspensions of cultures of the microorganism did kill 14 out of 20 larvae of Colias philodice eurytheme Bdvl. (fig. 12), no deaths resulted from administering the microorganisms by mouth along with the insects' food.

Inasmuch as the known natural habitat of $\boldsymbol{P}$. pullulans is largely the surfaces of plants, and inasmuch as the washings of the twigs and of the external surfaces of the insects used in this investigation frequently yielded abundant cultures of $P$. pullulans, there was good reason to suspect the source of this fungus in cultures made from what were assumed to be the insects' body contents. Furthermore, careful microscopic examination of the external surfaces of the insects commonly showed varying numbers of oval forms of $P$. pullulans, as well as Hormodendrum, adhering to the integument, and occurring in integumental folds and in intersegmental areas. The greatest of care would have to be taken to avoid contamination by these forms.

Accordingly, the culture experiments were repeated with special efforts made to detect and avoid the external, symbiote-appearing forms of $P$. pullulans. The insects were immersed in tincture of Merthiolate (1:1000) for 2 to 4 minutes, followed by four or five washings in 70 per cent ethyl alcohol, which in turn was followed by five rinsings in sterile saline. The insects were then either triturated in sterile saline and the resulting suspension cultured, or their body contents were pressed out on a sterile glass slide, then transferred to the culture medium. Using such techniques, only rarely did $P$. pullulans appear in the cultures.

Inasmuch as it is possible that the treatment with Merthiolate and alcohol was such as to injure or prevent the growth of the symbiotes, other procedures were used. The most significant results were obtained with hanging drop preparations. Briefly, these results were as follows: In hanging drops in which the body contents were suspended in their own fluids or in liquid media such as Hansen's solution or malt extract broth, the few individuals of $P$. pullulans coming apparently from the exterior of the insect multiplied rapidly, frequently "filling" the drop in from 24 to 48 hours. In numerous preparations in which the same field was held under the microscope for as long as 17 days the symbiotes were never seen to grow even though the $P$. pullulans may have developed luxuriantly. Occasionally, some slight elongation and budding of the symbiotes were seen but no really marked or dynamic changes were apparent. In hanging drops in which the liquid medium contained the body contents of insects that had been treated externally with Merthiolate, the symbiotes did not grow beyond some budding, nor did $P$. pullulans appear even after 7 to 10 days. That the hanging drops were able to support microbial growth was indicated by the luxuriant growth of bacteria that usually developed after several days. Many experiments of this type, and variations thereof, were run but in no instance was any extensive growth seen to arise from the symbiotes themselves. 
In order to compare serologically the symbiotes as seen in the body cavity of the insects with the forms previously cultivated, antisera were prepared in rabbits against two of the strains of $P$. pullulans grown on malt extract agar. When symbiotes taken directly from the insects were suspended in varying dilutions of these antisera no appreciable agglutination or other significant reaction occurred using the standard tube method. These results disclosed that the cultivated Pullularia and the symbiotes were not identical, even though the homologous antigens (i.e., the cultivated $P$. pullulans) reacted in high titers. In hanging drops of the concentrated antisera, the symbiotes were frequently seen to gather in loose groups (unlike the situation observed in the controls), while the homologous Pullularia antigen clumped into closely packed groups. These results might denote a possible distant relationship between the symbiote and the cultivated Pullularia. In any case, no results were obtained from any of the serological tests run that would indicate that the symbiotes and the cultivated Pullularia were the same organism.

From the foregoing, it would appear that the $P$. pullulans, at first so readily cultivated from the Coccidae examined, does not arise from the symbiotes harbored within the bodies of the insects. The evidence we have obtained for this assertion is pertinent since it may explain some of the reports of earlier workers who believed they had successfully cultivated the yeastlike symbiotes from coccids. Especially might this apply to those reports (e.g., by Brues and Glaser, 1921) in which the supposed cultivated symbiotes were determined as Dematium (i.e., Pullularia?). In this regard we are inclined to echo the warnings of Schwartz (1924) who, like Buchner (1921) before him, found an abundance of fungus and yeast forms (similar in appearance to the internal symbiotes) on the body coverings of scale insects, including Lecanium corni, and who pointed to the great danger in considering these forms as identical to the symbiotes.

Despite our inability, at this time, to identify the symbiotes with the strains of $P$. pullulans cultivated on artificial media, there is left room for speculation as to the possibility that the symbiotes are, nevertheless, phylogenetically related to Pullularia or the "black yeast" group, or, depending on the classification followed, to the genera Dematium or Torula. That they belong somewhere in the tribe Toruleae Saccardo seems likely. It cannot be denied that morphologically the symbiotes resemble the blastospores of $\mathrm{Pul}$ lularia, although for the most part those we have observed are consistently somewhat smaller in size than those of the P. pullulans grown on artificial media. Moreover, there is the possibility that the symbiotes represent forms of Pullularia originally living on the surfaces of plants but now adapted to living in the body tissues and fluids of the insect. It is not impossible that such a relationship could have arisen as the result of the constant association of the insects with the free-living Pullularia.

\section{ATTEMPTS TO UPSET THE INSECT-SYMBIOTE BALANCE} One of the most surprising aspects of the relations between insects and their mutualistic symbiotes is the obvious maintenance of a satisfactory balance between the two forms of life. What, for example, prevents the microbial 
symbiotes from increasing in number to a point at which they could overwhelm the host insect? Although it has been a matter of speculation by numerous authors, the exact nature of these checks and balances is not known. If a procedure were discovered by which this balance could be upset, at will, to the disadvantage of the host, a new method of controlling the latter might emerge. It is conceivable that the insects could be harmed if they were deprived of their symbiotes or, on the other hand, if the symbiotes could be made to increase and develop to an extent detrimental to the host. None of our attempts to accomplish this has been successful.

Use of Antibiotics. The cut ends of pear twigs bearing Lecanium corni were placed in solutions of various antibiotics: penicillin (Parke, Davis), streptomycin (Merck), aureomycin (Lederle), terramycin (Pfizer), rimocidin sulfate (Pfizer), polymyxin B sulfate (Pfizer), and actidione (Upjohn). No significant results were obtained using most of these antibiotics. However, during the course of some of the experiments using actidione and polymyxin B sulfate, many elongated and "abnormal" forms of the symbiote were seen. To a lesser extent these forms also occurred in the untreated controls, so if the antibiotics played any role in bringing them about, it was probably only that of enhancing or accelerating the changes that occur naturally. Many detailed experiments were conducted using these two antibiotics because at times, especially with polymyxin in concentrations of from 0.5 to $5.0 \mathrm{mg}$ per $\mathrm{ml}$ of water, the symbiotes in the test insects appeared to be reduced in numbers and altered in morphology, and the insects frequently died. However, numerous replicates of these experiments failed to reproduce these results consistently, and frequently no detectable changes in the morphology or number of the symbiotes appeared.

Of interest is the fact that in two rather large experiments using polymyxin B sulfate (in concentrations of 0.1 to $5.0 \mathrm{mg}$ per $\mathrm{ml}$ of water), a higher percentage of mortality of the insects was noticed on the twigs placed in the antibiotic than in the controls placed in ordinary tap water. In one experiment, 57 per cent of the insects on polymyxin-treated twigs died over a 21-day period, as compared with a mortality of 13 per cent in the untreated controls. In another experiment, 28 per cent of the insects on the antibiotictreated twigs died while there was a 14 per cent mortality on the control twigs. A somewhat greater number of these dead insects appeared to harbor elongated growth forms of the symbiote than did the living, apparently healthy, insects. Whether or not any significance should be attached to this difference in mortality is difficult to say. Subsequent smaller experiments did not consistently yield confirmatory results. A field experiment in which polymyxin was sprayed on scale-infested pear trees gave no promise that this antibiotic would be applicable in the control of the insect.

Experiments in which indol-3-acetic acid and thiamine hydrochloride were tried in a manner similar to that used in the case of the antibiotic experiments failed to show any growth-promoting effects on the symbiotes.

Oxygen Tension. To test the possibility that the growth of the symbiote in the insect is held in check by the low amount of oxygen in the insect's circulating blood, scale-infested ( $L$. corni) twigs were placed in chambers in which the air was replaced by an atmosphere of pure oxygen. This oxygen 
bath was maintained continuously for 14 days. The examination of approximately 200 insects from these twigs failed to reveal any inordinate amount of growth or increase in numbers on the part of the symbiote. Similar negative results accrued from an experiment in which the air in the chambers was replaced by carbon dioxide.

Hydrogen-Ion Concentration. Although the hemolymph of coccids is sufficiently buffered not to permit much of a change in its $\mathrm{pH}$ as a result of an altered diet, it was felt wise at least to test for the remote possibility that the symbiotes in scale insects feeding on twigs placed in solutions of various hydrogen-ion concentrations might somehow be affected. Buffered aqueous solutions having $\mathrm{pH}$ values of $3.0,5.2,6.2,7.0,8.2$, and 9.2 were prepared and in them were placed twigs infested with $L$. corni. The insects on these twigs were examined over a two-week period. In no case were any significant changes noticed in the number or morphology of the symbiotes even though, in solutions having the extremes in $\mathrm{pH}$, the twigs themselves showed deleterious effects.

Extreme Temperatures. It is well known (e.g., in the case of the protozoan symbiotes in termites) that some insects may be freed of their symbiotes by subjecting them to abnormally high temperatures, i.e., temperatures that destroy the symbiote but permit the insect to survive. Accordingly, we placed scale-infested ( $L$. corni) twigs in temperature cabinets at temperatures of $50^{\circ}, 40^{\circ}$ and $4^{\circ} \mathrm{C}$ for periods of two weeks. At the end of these periods the insects were examined but no change could be detected in their symbiotic picture.

Starvation and Desiccation. Scale-infested twigs, cut from pear trees in February, were allowed to die at room temperature. The insects were examined over a three-week period during which they underwent starvation and desiccation. Although the insects died, no significant changes were observed in the morphology of the symbiotes.

From the various experiments here recounted, it is clear that the methods and techniques used do not appear to be adequate to cause an upset in the insect-symbiote balance. At any rate, none of them enabled us convincingly to free the insects of their symbiotes nor, on the other hand, to cause the symbiotes to increase excessively in numbers or in growth forms. Elongated developmental forms were occasionally seen in the insects under test, but in no instance did they exceed the incidence of the same forms in the normal controls.

\section{GROWTH FORMS}

The microscopic examination of a smear or wet mount made of the hemolymph of any of the coccid species concerned in the present investigation usually revealed the symbiote to be the type of budding, yeastlike organism described earlier in this paper (e.g., figures 2, 5, and 7). Our study had not progressed far, however, before we began to notice that many of the symbiotes in an occasional insect were considerably elongated as compared with the form usually encountered. We first observed these elongated forms (fig. 13) in our experiments designed to determine the effect of polymyxin on the symbiotes. Indeed, a variety of forms was seen. The most frequent atypical 
formation was that in which the symbiotes became greatly elongated. In other cases, the symbiotes appeared simply to enlarge without appreciably lengthening, presenting a slightly swollen appearance. Occasionally the symbiotes appeared abnormally small. In some host specimens, one or another of these "abnormal" forms predominated, in other individuals there was a mixture of two or more types. At first we believed that these atypical forms represented abnormalities caused by the polymyxin, and in another instance by the actidione, being used in the experiments. It soon became evident, however, that similar atypical symbiotes occurred just as occasionally in untreated and, from all appearances, perfectly normal scale insects, i.e., the controls.

Here, it seemed to us, was strong evidence that under certain conditions, not yet clear, the symbiotes found themselves free to develop into larger forms, which we might call "growth forms." It appeared as though ordinarily something (probably originating in the insect) inhibited or restrained the symbiote from developing freely and, instead, held it to a carefully regulated number of the small blastospore or sprout-cell form. Indications were that if the inhibitor could be nullified the symbiote would grow and develop into a hyphal fungus. It was obvious, as it is with all intracellular symbiotes, that the number of symbiotes permissible to live in any one insect is limited. But is this the result of the activity of the same restraining or inhibiting mechanism that checks or controls the size and development of the symbiote?

About this time, an important paper by Schwartz (1932) came to our attention. In this paper, the author reported on observations similar to those made by us and suggested that the symbiotes of $L$. corni are subject to a "formative" as well as a reproductive restraint or inhibition (Hemmung). According to Schwartz, the reproductive restraint hinders an excessive increase in the number of symbiotes in the insect, and its absence leads to the filling of the hemolymph with symbiotes. The formative restraint holds the symbiotes to the sprout-cell stage and prevents the growth of hyphae.

Schwartz felt that the increase and decrease or the presence and absence of the restraining principles were associated with the age (or stage) of the insect. In the eggs and in the crawlers both types of inhibition appear to be especially strong. During the period of the insect's vigorous growth and up to the time that egg-laying begins, there is a diminution of the reproductive restraint. According to Schwartz there is no release or lessening of the formative inhibition until toward the end of and after the egg-laying period. He believes this to be due to the presence of some specific factor which disappears with certain changes in the hemolymph caused by aging. Phagocytosis, he believes, is involved as a process regulating the number of cells that are formed. (We, too, noticed instances of phagocytosed symbiotes.)

While the results of our own studies are compatible with Schwartz's concept of the presence of reproductive and formative restraints, we did not find the activity of the formative restraining principle to be solely a matter of age. The elongated hyphal forms that would indicate a lessening of the formative restraint were found present in certain percentages at every age and in every stage including even the egg. 
During the month of October, 1954, when the insects were in early immature stages, at least 2 per cent of apparently normal scale insects harbored elongated forms. However, in one experiment, in December, over 600 healthy insects were examined and only one individual showed definite elongated forms. This was exceptional, and at times the percentage of normal young insects harboring the elongated symbiotes approximated 25 per cent on certain twigs. In general, however, it appeared that on any given twig elongated symbiotes were found more frequently in dead and apparently dying insects than in living, healthy individuals. For example, in one experiment it was observed that of 142 young dead insects, 30.0 per cent showed elongated forms, while of 153 living insects, only 9.1 per cent harbored the elongated symbiotes. In another instance, in March, counts were made of 50 dead insects and of 50 healthy insects. Of the dead insects, 21 (42 per cent) showed the presence of elongated growth forms, while 29 (58 per cent) did not. Of the 50 living insects, 5 (10 per cent) showed numerous elongated growth forms, 4 (8 per cent) showed very few such forms, and 41 (82 per cent) showed no elongated growth forms.

Thus it would appear that the occurrence of markedly elongated growth forms of the symbiote may not be so much (or entirely) a matter of age, as concluded by Schwartz, as it is a reflection of the state of the insect's health or vitality. (Yet they do occur in healthy insects.) We are not suggesting, however, that the death of the host is caused by the abnormal development of the symbiote, although at times this may be a contributing factor. Schwartz's observation that these forms occurred mostly in older adults may be largely because of the devitalization of the insects at that time. He found no relation between their presence and alterations in the nutrition of the host plants. In any case, the data now available on this point are not of the quality or quantity that would permit a dogmatic conclusion.

\section{SUMMARY}

Although research directed toward revealing the nature of the relationships between soft scale insects and their symbiotes is difficult and time-consuming, the investigation herein reported yielded a few results worthy of note. The principal points may be summarized as follows:

1. Limited observations were made on the yeastlike symbiotes of certain Coccidae (Lecanium corni Bouché, Lecanium kunoensis Kuwana, Saissetia oleae (Bern.), and Saissetia nigra (Niet.)). That of $L$. kunoensis is described for the first time. Attempts were made to cultivate the symbiotes on a variety of artificial media under a variety of conditions, but no definite success was obtained. Contaminating microorganisms (especially Pullularia) commonly confused the picture and great care must be taken to eliminate these extraneous forms.

2. In many respects the symbiotes of the coccids studied are suggestive of the so-called "black yeasts" of which Pullularia (=Dematium) pullulans (De Bary) is the best known species. This fungus was found to occur on the external surfaces of the coccids and to be abundant in the environment of the insect (i.e., on the twigs and foliage of the host plant). It is not impos- 
sible that the symbiotes in the insect have a phylogenetic relationship to the free-living Pullularia, and that long ago the symbiotic arrangement grew out of the constant association between the insect and the Pullularia in its environment.

3. On a theoretical basis it would appear possible to control certain coccids by altering the biological relationships between them and their symbiotes. It is conceivable that this might be accomplished by altering the insect's environment so as to destroy the symbiote, or so as to cause the symbiote to become pathogenic for its host, or to multiply to a degree that would cause the death of the host. However, attempts to upset the insect-symbiote balance by the use of antibiotics, changes in oxygen tension and hydrogen-ion concentrations, and subjecting the insect to abnormal temperatures, desiccation, and starvation, all failed; at least they failed to alter the symbiotic picture consistently.

4. Elongated growth forms of the symbiote were observed in a certain percentage of the insects at various ages. It would appear that the occurrence of these elongated forms may not be solely a matter of age, as some workers believe, but at times and to some extent at least, a reflection of the state of the insect's health or vitality. Our observations tend to confirm the idea that the symbiotes of coccids are subject to inhibitory principles which restrain them from excessively (for the host) increasing in numbers and from developing elongated or hyphal growth forms.

\section{ACKNOWLEDGMENTS}

The author wishes to acknowledge with sincere thanks the technical assistance, during parts of this investigation, of Elizabeth A. Jerrel and Catherine L. Boerke. He is grateful to Professor Herman J. Phaff of the University of California at Davis for helpful suggestions and advice relative to the nature of the yeastlike forms studied. Thanks are also extended to Chas. Pfizer \& Company for providing generous supplies of rimocidin sulfate and polymyxin $B$ sulfate used during these experiments.

\section{LITERATURE CITED}

BENEDEK, T., and G. SPECHT

1933. Mykologischbakteriologische Untersuchungen über Pilze und Bakterien als Symbionten in Kerbtieren. Zentbl. f. Bakt. Parasitenk. Infekt. Abt. I Orig. 130:7490.

Berkhout, C. M.

1923. De Schimmelgeslachten Monilia, Oidium, Oospora en Torula. Doctorate Dissertation; Rijks-Universiteit te Utrecht. Edauw \& Johannissen, Scheveningen. $71 \mathrm{pp}$. BERLÈSE, A.

1895. Première contribution a l'étude de la morphologie et de la biologie de Cladosporium et Dematium. Soc. Mycol. de France Bul. 11:34-74.

1905. Sopra una nuova specie mucidinea parassita del Ceroplastes rusci. Redia 3:8-15. [Published in 1906.]

BraIN, C. K.

1923. A preliminary report on the intracellular symbionts of South African Coccidae. Ann. Univ. Stellenbosch 1:1-48. 
Brooks, F. T., and C. G. HANSFORD

1923. Mould growths upon cold storage meat. Brit. Mycol. Soc. Trans. 8 (Part 3): $113-41$.

Brues, C. T., and R. W. Glaser

1921. A symbiotic fungus occurring in the fat body of Pulvinaria innumerabilis Rath. Biol. Bul. $40: 299-324$.

BUChNER, $\mathrm{P}$.

1911. Ueber intrazellulare Symbionten bei zuckersaugenden Insekten und ihre Vererbung. Sitzber. Ges. Morph. Physiol. [München] 27:89-96.

1912. Studien an intracellularen Symbionten. I. Die intracellularen Symbionten der Hemipteren. Arch. Protistenk. 26:1-116.

1921. Tier und Pflanze in intracellularer Symbiose. Gebrüder Borntraeger, Berlin. $462 \mathrm{pp}$.

1953. Endosymbiose der Tiere mit Pflanzlichen Mikroorganismen. Berkhäuser. $771 \mathrm{pp}$. Constantin, J.

1888. Les Mecédinées simples. Klincksieck, Paris. p. 143.

CONTE, A., and L. FAUCHERON

1907. Presence de levures dans le corps adipeux de divers coccides. [Paris] Acad. des

De BARY, A.

Sei. Compt. Rend. 145:1223-25.

1866. Morphologie und Physiologie der Pilze, Flechten und Myxomyceten. W. Engelmann, Leipzig. $316 \mathrm{pp}$.

DODGE, C. W.

1935. Medical mycology. Fungous diseases of men and other mammals. C. V. Mosby Co., St. Louis. 900 pp.

Frank, A. B.

1886. Specielle Botanik. Kryptogamen. Part III of Synopsis der drei Naturreiche by Johannes Leunis. Synopsis der Pflanzenkunde. Hahn'sche Buchhandlung, Hannover. $675 \mathrm{pp}$.

Granovsky, A. A.

1929. Preliminary studies of the intracellular symbionts of Saissetia oleae (Bernard). Wisconsin Acad. Sci., Arts, Letters Trans. 24:445-56.

\section{HOGGAN, I.}

1924. On Dematium pullulans De Bary. Brit. Mycol. Soc. Trans. 9:100-07.

JANCZEWSKI, E.

1892. Polymorphisme du Cladosporium herbarum. Acad. Sci. Gracovie Bul. 10:417-22.

KLOCKER, A., and H. SCHIONNING

1900. Phenomènes d'accroissement perforant et de formation anormale des conidies chez le Dematium pullulans, De Bary, et autres champignons. Carlsberg Lab. Compt. Rend. des Trav. 5:47-57.

\section{LAURENT, M. E.}

1888. Recherches sur la polymorphisme du Cladosporium herbarum. Inst. Pasteur Ann. [Paris] 2:581-88.

LINDNER, $\mathrm{P}$.

1895. Ueber eine in Aspidiotus nerii parasitisch lebende Apiculatus-hefe. Zentbl. Bakt. Parasitenk. Infekt., Abt. II, 1:782-87.

LOEW, E.

1867. Über Dematium pullulans De Bary. Jahrb. f. Wiss. Bot. 6:467-77.

MASSEe, G.

1898. Gummosis of Prunus japonica. Thub. No. 144. Royal Gardens, Kew. Bul. Misc. Information : $321-25$.

Moniez, R.

1887. Sur un champignon parasite du Lecanium hesperidum (Lecaniascus polymorphus nobis). Soc. Zool. de France Bul. 12:150-52.

Mrak, E. M., and H. J. PhAFF

1948. Yeasts. Ann. Rev. Microbiol., Ann. Revs., Inc. [Stanford] 2:1-46.

MüLLER, W.

1934. Untersuchungen über die Symbiose von Tieren mit Pilzen und Bakterien. III. Über die Pilzsymbiose holzfressender Insektenlarven. Arch. f. Mikrobiol. 5:84147. 
Negroni, P., and I. Fischer

1942. Estudio micrologico de trienta cepas de Pullularia (Dematium) pullulans. Inst. Bact. Rev. [Argentina] 9:99-107.

Persoon, (c. H.

1797. Tentamen dispositionis methodicae fungorum in classes, ordines, genera et familias. Cum supplemento adjecto. $8^{\circ}$ Lipsicoe. $76 \mathrm{pp}$.

Planchon, L.

1900. Influence de divers milieux chimiques sur quelques champignons du grupe Dematiées. Ann. Sci. Nat. Botan. (Ser. 8) 2:1-248.

SCHWARTZ, W.

1924. Untersuchungen über die Pilzsymbiose der Schildläuse. Biol. Zentbl. 44:487-527.

1932. Untersuchungen über die Symbiose von Tieren mit Pilzen und Bakterien. II. Neue Untersuchungen über die Pilzsymbiose der Schildläuse (Lecaniinen). Arch. f. Mikrobiol. 3:453-72.

SмIтH, R. H.

1944. Bionomics and control of the nigra scale, Saissetia nigra. Hilgardia 16(5):22588.

Streinhaus, E. A.

1951. Report on diagnoses of diseased insects 1944-1950. Hilgardia 20 (22):629-78. ŠULC, $K$.

1906. Kermincola kermesina n.g. n.sp. und physokermina n.sp., neue Mikroendosymbiontiker der Cocciden. Sitzber. Kgl. Böhm. Ges. Wiss., Art. 19. 6 pp.

ZoPr, W.

1890. Die Pilze in morphologischer, physiologischer, biologischer und systematischer Beziehung. Eduard Trewendt, Breslau. 500 pp. 


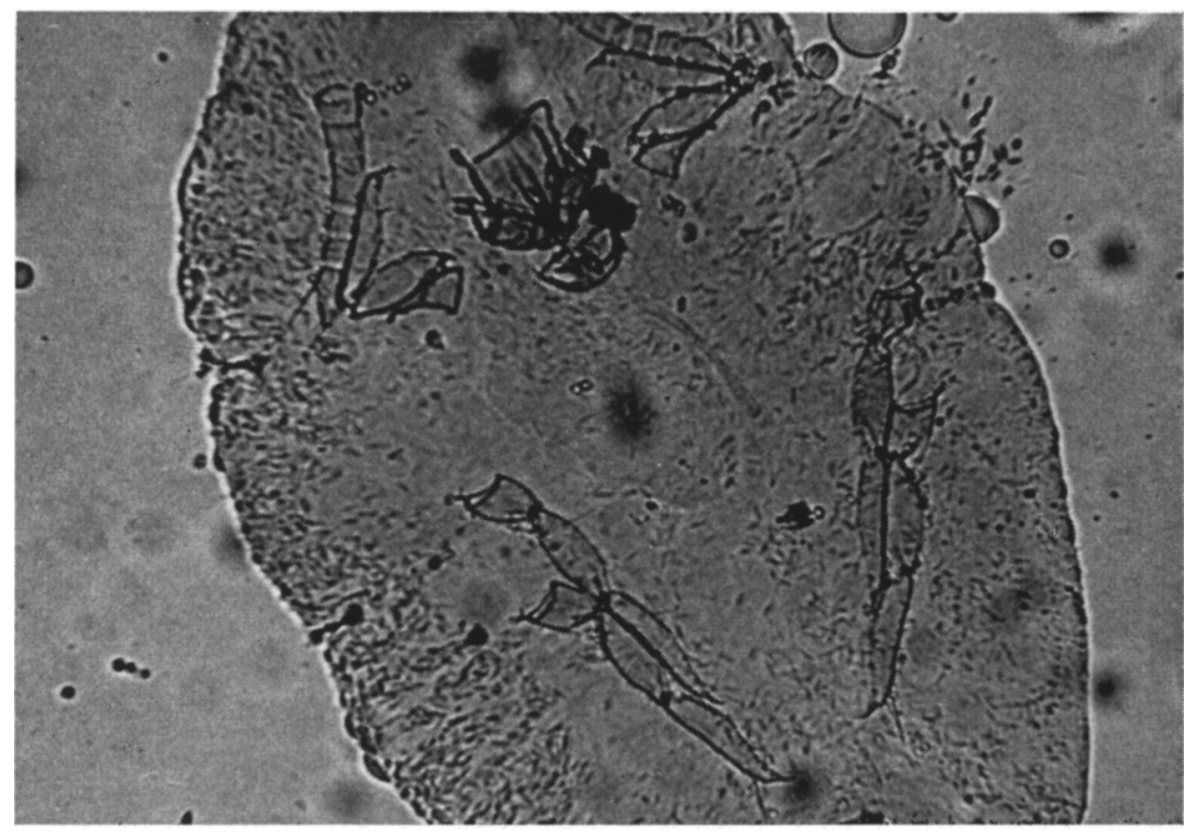

Fig. 1. Young Lecanium corni Bouché showing, by transmitted light, the symbiotes in situ within the insect's body cavity. Note the concentration of symbiotes toward the periphery of the insect.

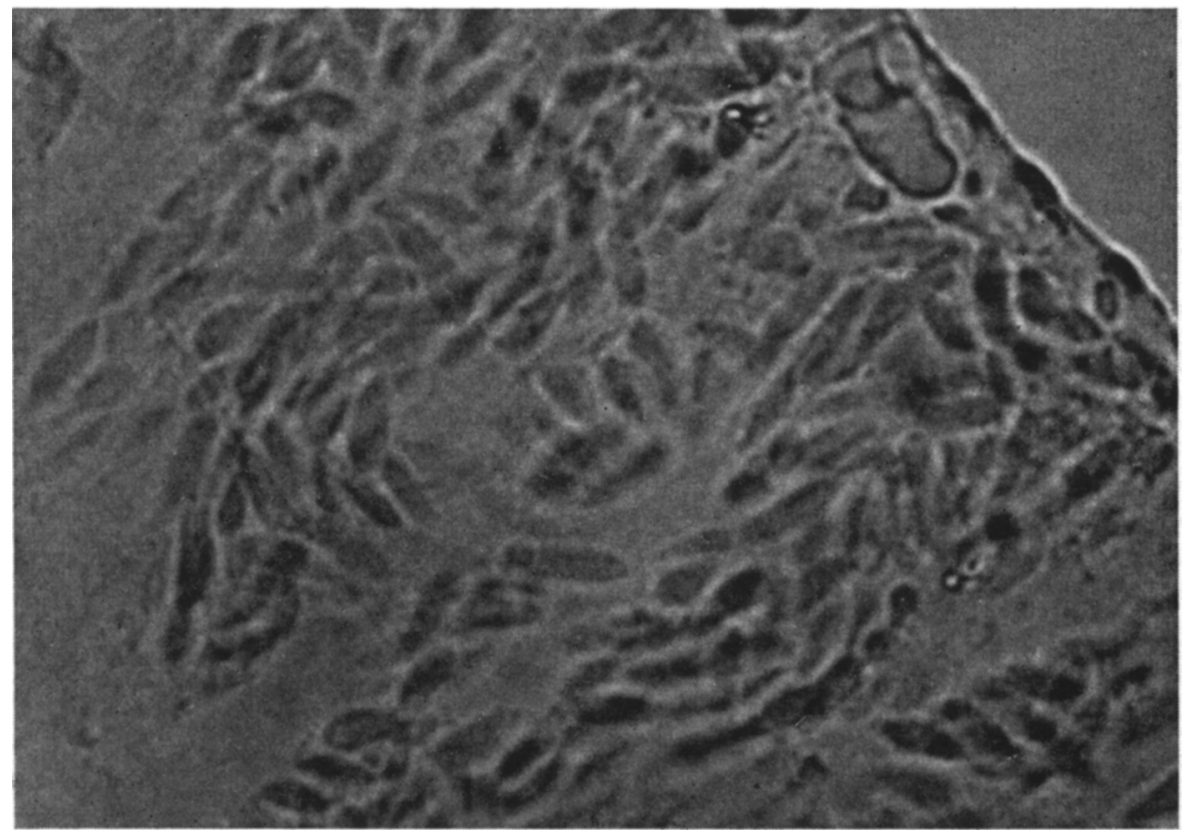

Fig. 2. Close-up of specimen shown in figure 1, showing the symbiotes within the body cavity of a young $L$. corni. 


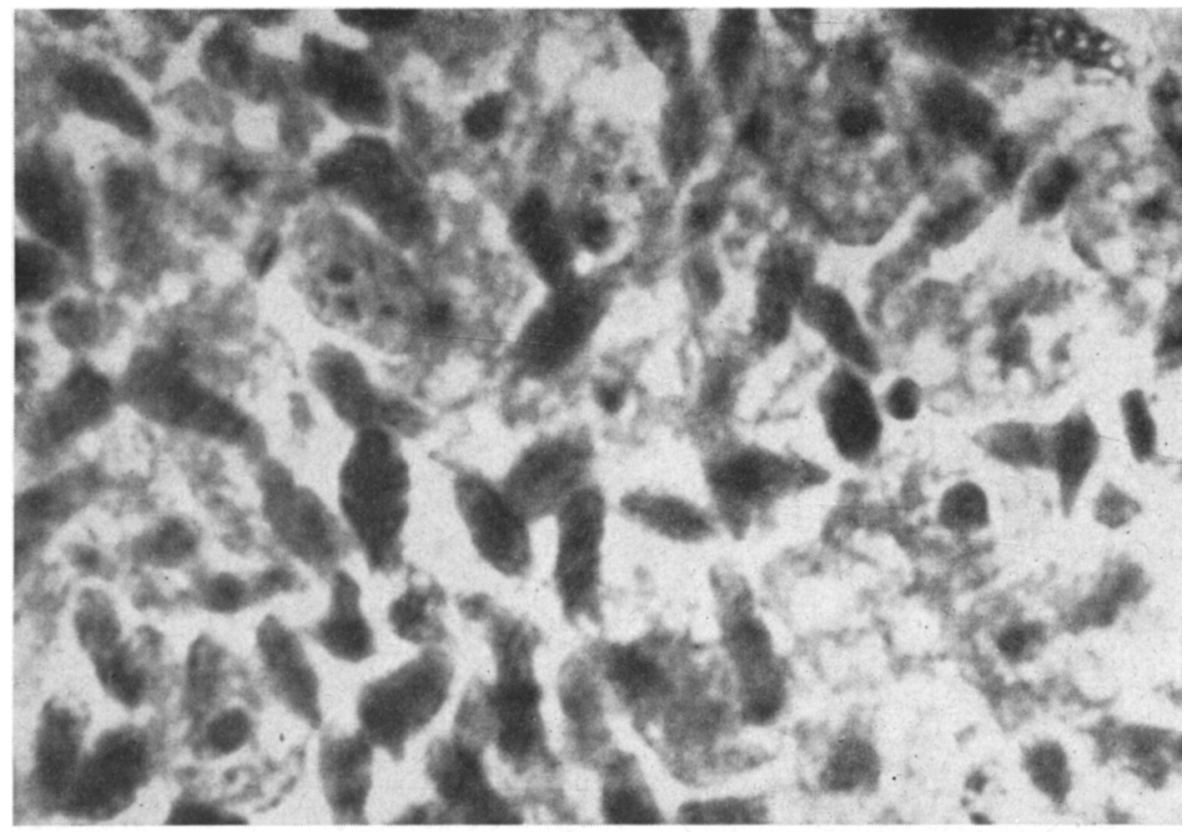

Fig. 3. Cross-section of a young adult $L$. corni showing the symbiotes (the darker ol,jects). Stained with iron hemotoxylin and eosin.

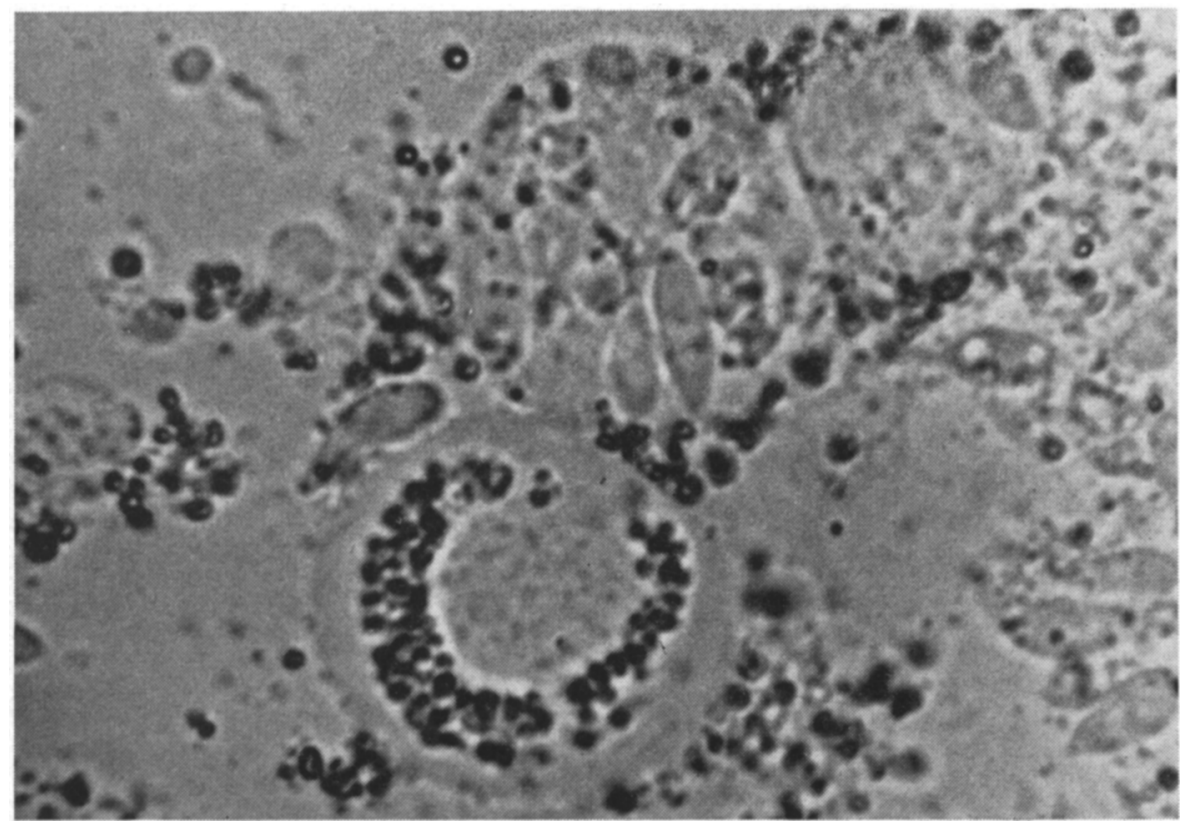

Fig. 4. Symbiotes of L. kunoensis within cells of the insect. 


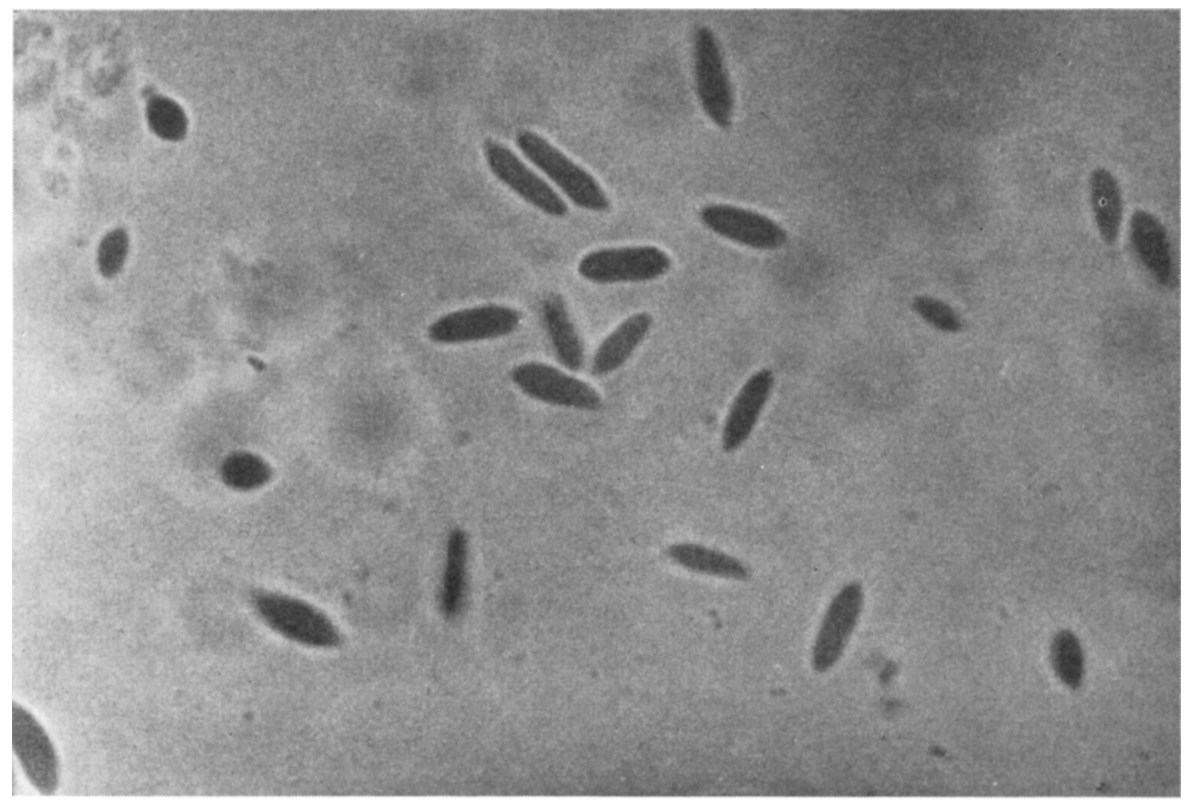

Fig. 5. Symbiotes free in the hemolymph of $L$. corni.

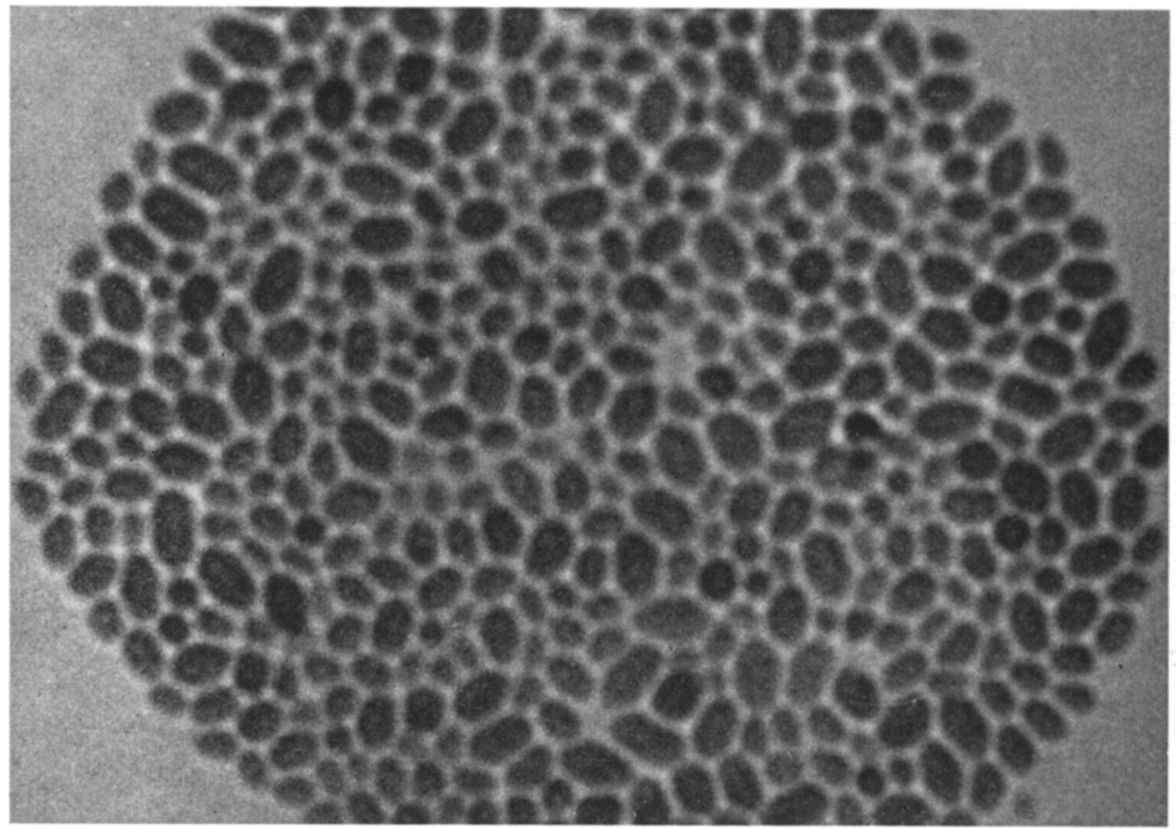

Fig. 6. Compact group of what are apparently atypical or developmental forms of the symbiote, as seen in the hemolymph of L. corni. 


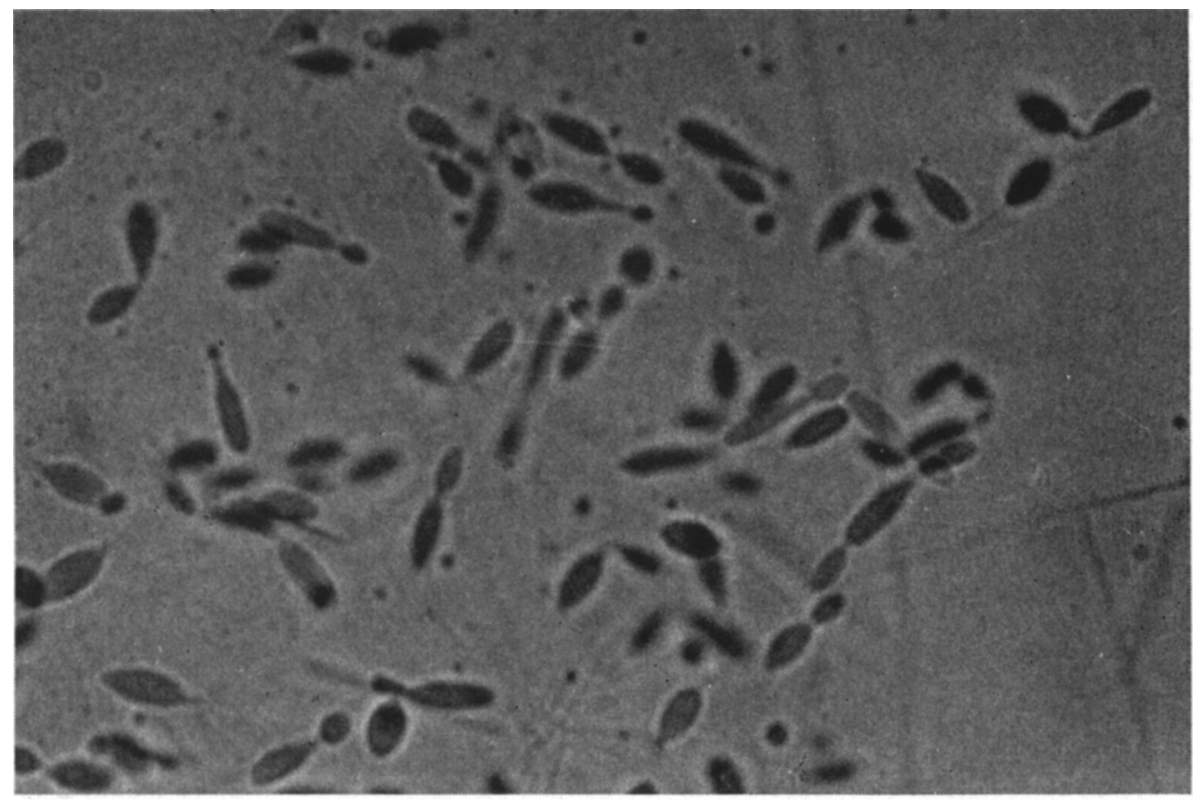

Fig. 7. Symbiotes from Saissetia oleae (Bern.). Wet mount preparation.

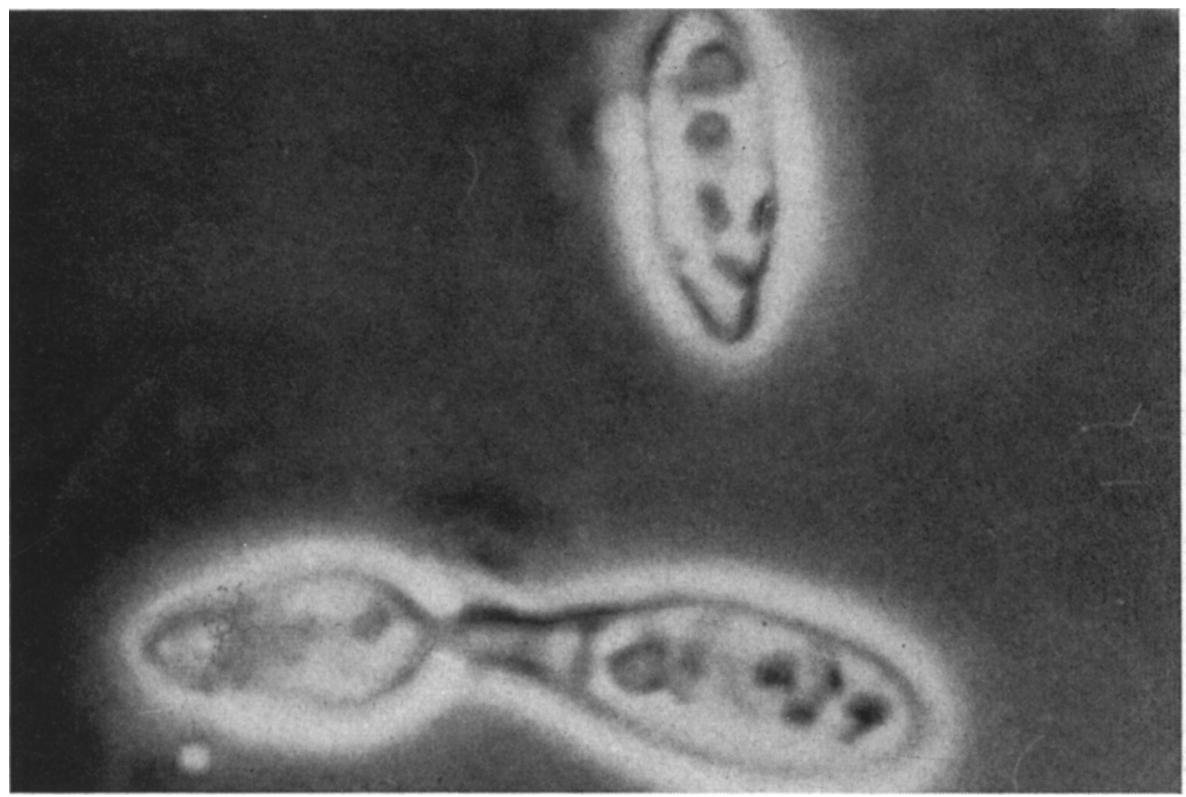

Fig. 8. Symbiotes of $S$. oleae as seen through a phase microscope. Note cellular contents. 


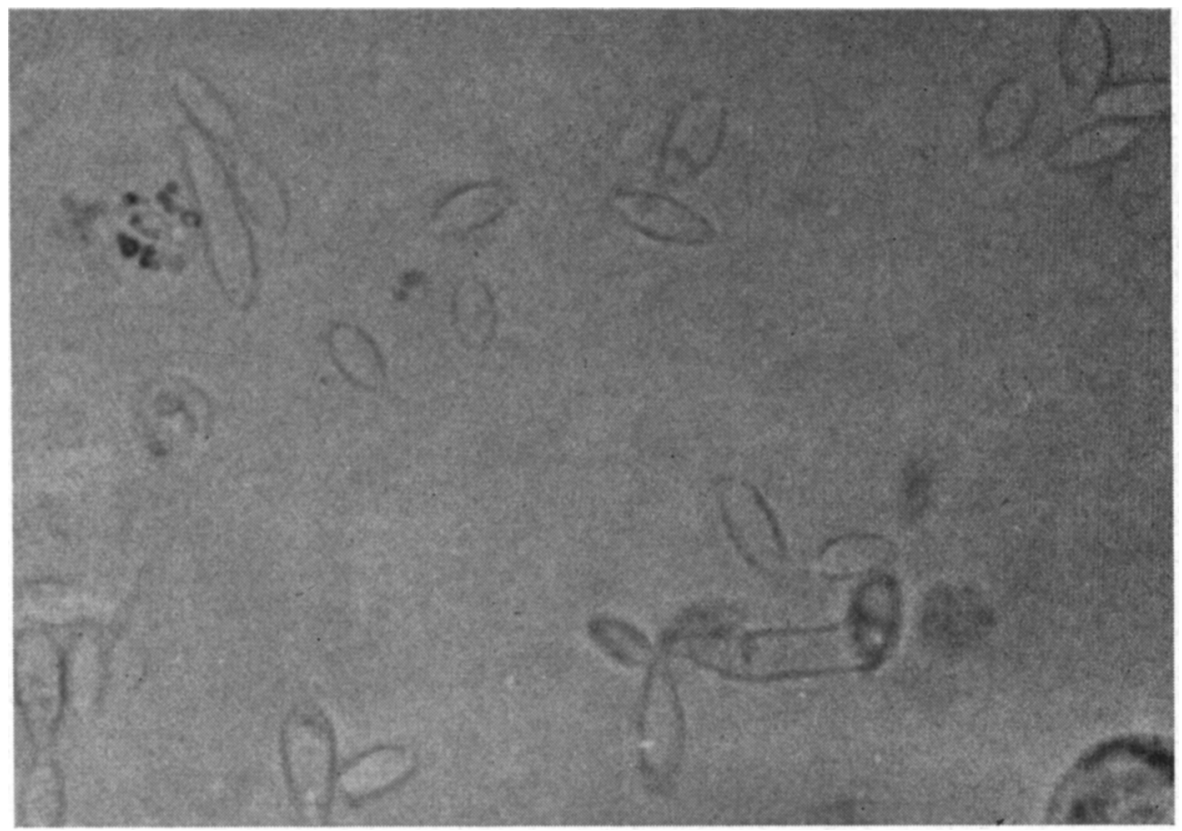

Fig. 9. Symbiotes of L. kunoensis in hemolymph of insect.

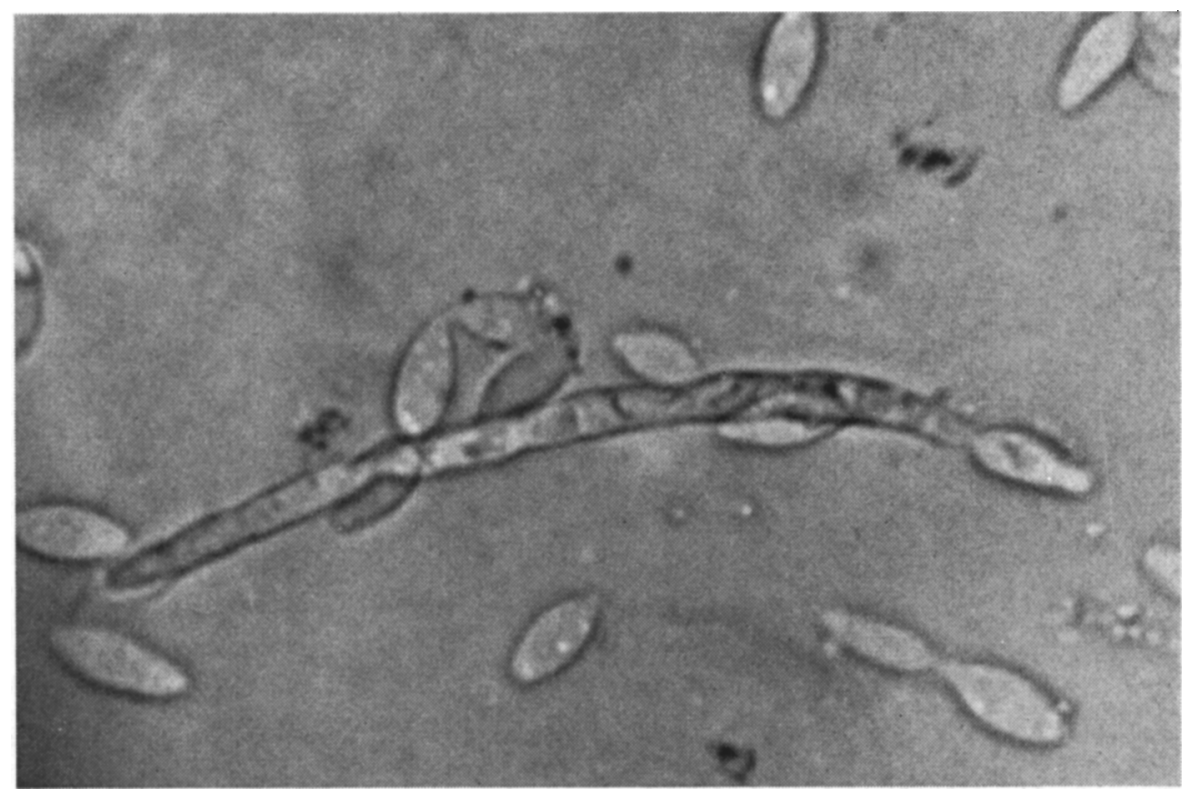

Fig. 10. Symbiotes of L. kunoensis in hemolymph of insect. One form considerably elongated. 


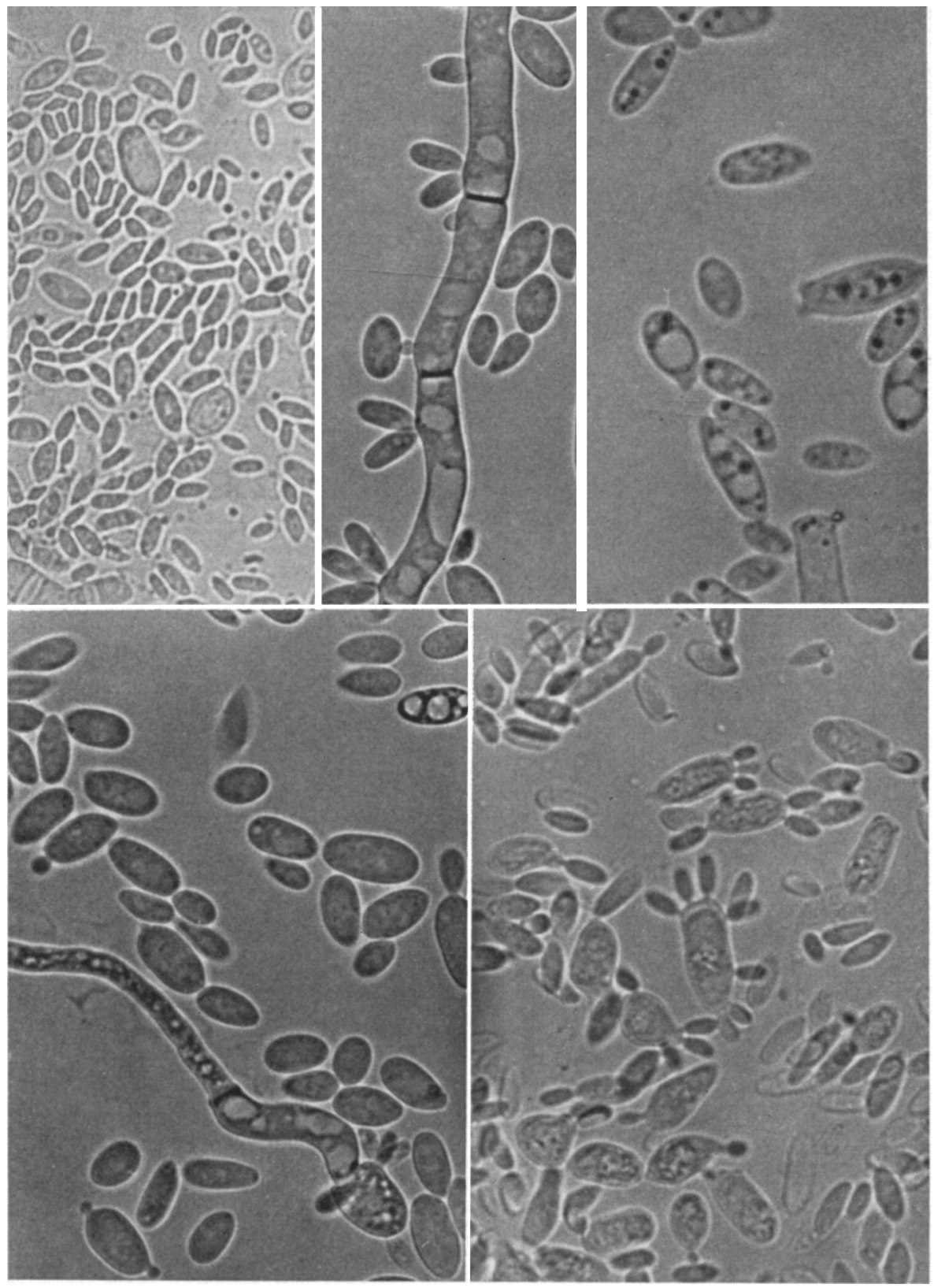

Fig. 11. Photographs of five strains of Pullularia pullulans (De Bary) isolated during attempts to eultivate the symbiotes of $L$. corni and L. kunoensis. Note general morphological resemblance of the blastospores in this figure to the symbiotes in figures 2 to 5 inclusive. 


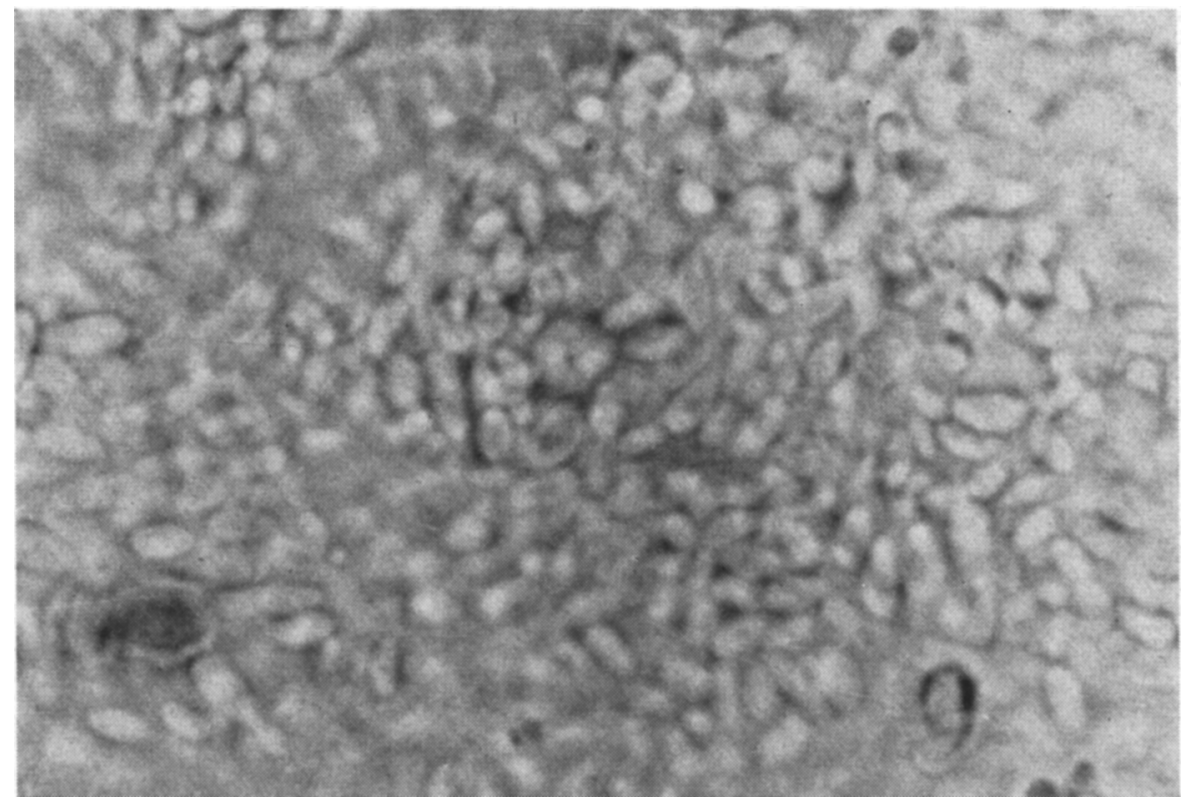

Fig. 12. Blastospores of Pullularia pullulans in tissues of a dead alfalfa caterpillar, Colias philodice eurytheme Bdvl., inoculated with a culture of the fungus three days previously. 

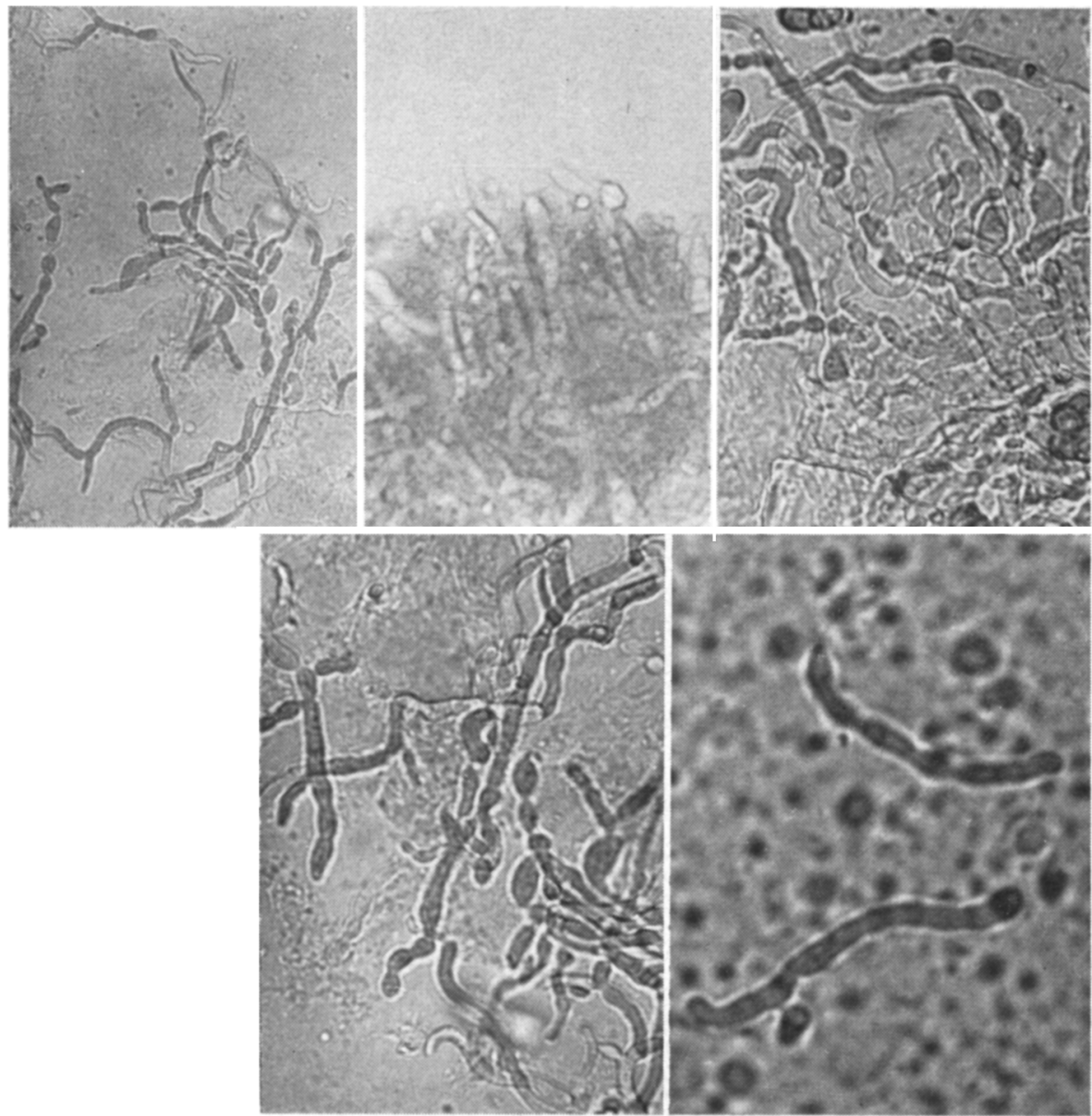

Fig. 13. Five views of elongated growth forms of the symbiotes of L. corni. 
The journal Hilgardia is published at irregular intervals, in volunes of about 600 pages. The number of issues per volume varies.

Subscriptions are not sold. The periodical is sent as published only to libraries, or to institutions in foreign countries having publications to offer in exchange.

You may obtain a single copy of any issue free, as long as the supply lasts; please request by volume and issue number form:
Agricultural Publications
Room 22, Giannini Hall
University of California
Berkeley 4, California

The limit to nonresidents of California is 10 separate issues on a single order. A list of the issues still available will be sent on request.

In our publications it is sometimes convenient to use trade names of products or equipment rather than scientific identifications. In so doing it is unavoidable in some cascs that similar products which are on the market under other trade names may not be cited. No endorsement of named products is intended nor is criticism implied of similar products which are not mentioned. 


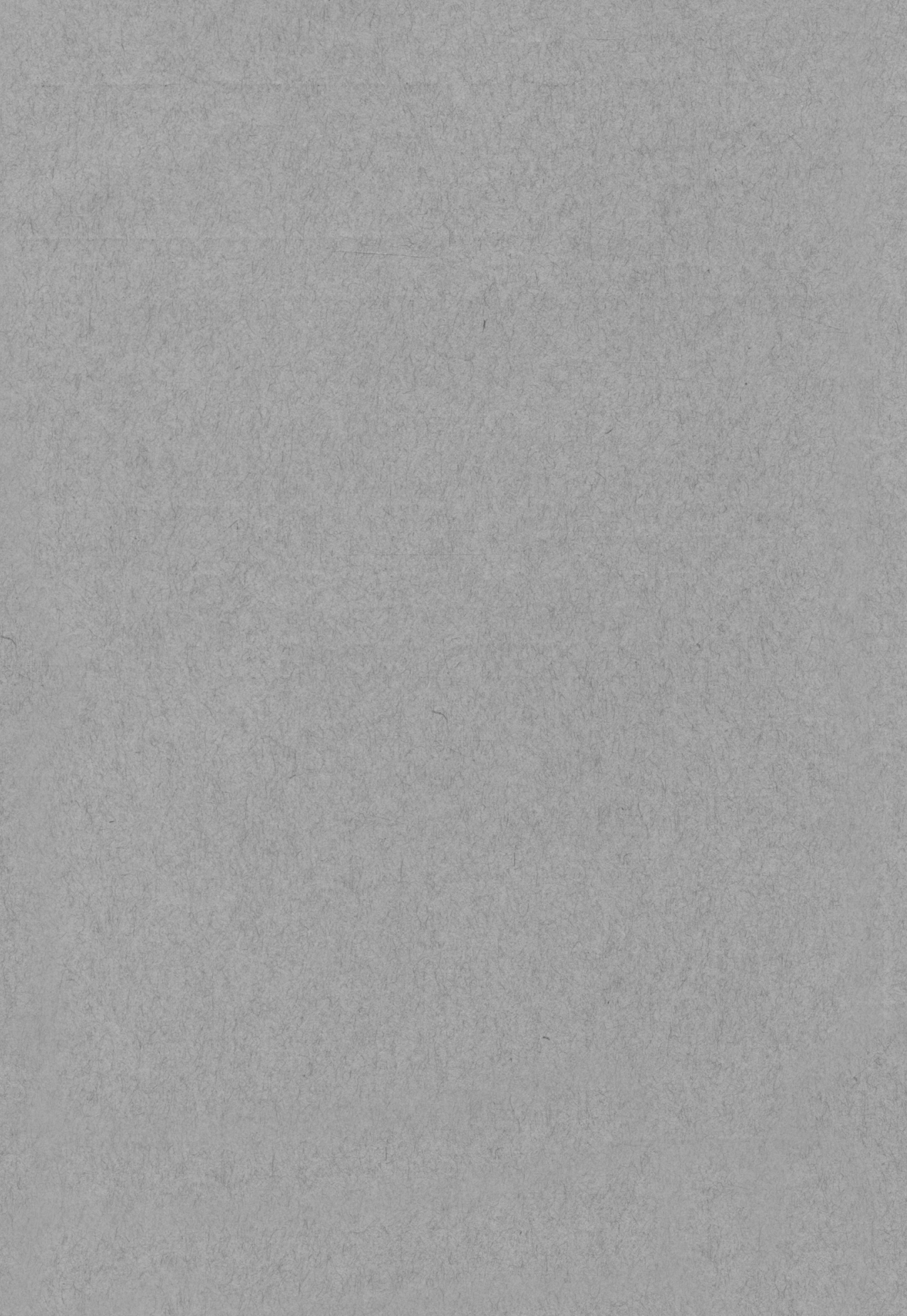

